\title{
Enhancing the Achievement in Physics' Motion Concept through Online Multiple Intelligence Learning Approach
}

\author{
Adri Nirwan Ahamad ${ }^{1 *}$, Mohd Ali Samsudin ${ }^{1}$, Mohd Erfy Ismail ${ }^{2}$, Nur Jahan Ahmad ${ }^{1}$ \\ 1 Universiti Sains Malaysia, Penang, MALAYSIA \\ 2 Universiti Tun Hussein Onn Malaysia, Batu Pahat, Johor, MALAYSIA
}

Received 26 October $2020 \cdot$ Accepted 28 January 2021

\begin{abstract}
The complexity of physics concepts in online learning environment probably will only benefit certain group of students. Thus, there are suggestions that the approach of delivering physics concepts in online learning environment shoud be conducted in various ways. The purposed of research was to investigate the effect of online multiple intelligence-based learning on achievement in physics' motion concept among $10^{\text {th }}$ grade students. The one group pre-test and post-test design were used in this research with purposive sampling, with 30 students in a science junior high school in Malaysia. In the research, the data were obtained from Multiple Intelligence Test and Physics Force and Motion Concept Test, which were analyzed using one-way ANOVA and non-parametric test Wilcoxon and Friedman. The findings reveal that online multiple intelligence-based learning had an effect on the achievement in physics' force and motion concepts with mathematical logic and Intrapersonal intelligence group performed significantly better than others.
\end{abstract}

Keywords: multiple intelligence, physics motion concept, online learning, science teaching

\section{INTRODUCTION}

Learning and teaching abstract and complex physics topic such as the force and motion require a variety use of technology in learning especially in using online learning tools and applications. Force and motion topics emphasize hands-on activity through conducting experiments in line with the syllabus studied (Wang, 2009). However, there are many challenges encountered by teachers especially in terms of the availability and limited number of laboratory equipment and tools (Pullit Lai, 1999). Therefore, online learning applications such as digital recorders, digital cathode ray oscilloscope or virtual applications like GraphPlotter could be utilised to overcome the challenges. Moreover, the online learning allows students to develop their own experimental experiences as well as enhancing their digital literacy skills. Furthermore, these experiences increase student's confidence at the same time enhancing their self-directed willingness to continue to explore new knowledge and learn on their own pace and capacity.
In physics classes, students often learn through discussions with teachers and classmates. It is reported that the discussion in conventional classrooms is still lacking among students as teachers being the main contributors to provide information to students (Chin \& Kayalvizhi, 2005; Shy-Jong, 2007). For some topic such as vectors in linear motion involves problems solving which requires students to draw free-body-diagram on the concept of force. In order to do this, students completely depend on teachers to guide them and constantly ask questions. Unfortunately, teacher unable to spend time to answer the same student every time. On the contrary, by using online learning with video application such as YouTube, this allows students to download instructional videos and view the teacher's explanations repeatedly. In addition, the use of online communication applications such as WhatsApp allows students to ask their teacher or fellow friends privately. Moreover, another online learning like flipped classroom also provides the technology for students to collaborate, discuss, participate in students' group projects (Chien, Chen, \& Liao, 2019). It involves elements of communication and collaboration that help students

(c) 2021 by the authors; licensee Modestum. This article is an open access article distributed under the terms and conditions of the Creative Commons Attribution License (http://creativecommons.org/licenses/by/4.0/).

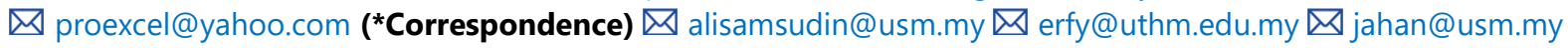




\section{Contribution to the literature}

- This paper describes the uses of online technologies for learning Physics force and motion concept.

- The author present brief description how multiple intelligence can be integrated with online technologies.

- The results showed that the online learning integrating multiple intelligences method was able to have a positive effect on students' achievement.

learn better in a cooperative environment and this can enhance students' understanding of the subject of physics itself (Ho \& Bo, 2007).

The uses of variety of learning methods and online technologies requires multiple intelligence in order for students to succeed in their learning. In 1983, Gardner introduced Multiple Intelligence which proposed that each individual possesses eight intelligences namely: logic-mathematic, visual-spatial, kinesthetic, verballinguistic, musical, interpersonal, intrapersonal and naturalistic. Therefore, student tend to learn in their own way using their dominant intelligence.

Learning science especially physics subject in the classroom is considered difficult because it has many abstracts and scientific terminologies (Erinosho, 2013). Students do not understand the abstract ideas in physics because it is beyond their own experiences that are not related to real-world experiences. These makes difficult for the students to grasp the physics concepts and apply it in solving problems in the real life (Mantyla \& Koponen, 2007). Force and motion are topics that are often considered difficult and are often associated with the challenges in understanding abstract concepts of Newton's Law (Goff, 2004) such as the concept of force (Neset, 2005), the fundamentals of linear motion (Nik Daud, Abd Karim, Wan Hassan, \& Rahman, 2015), impulses and momentum (Lawson \& McDermnt, 1987) and the uses and application of graph (Hale, 2000; Leela, 2016). Both topics are included in science syllabus in Malaysia and these topics are the focus in this study.

Students also often find that learning physics in the classroom is very tedious and requires good memorization of formulas and good mathematical mastery in solving exam questions (Halpern, 2002). For an example, in the topic of linear motion and linear motion graph, memorization of the linear motion formula and finding math solutions using those formulas are required for students to solve the problem. This makes it difficult for those students who cannot memorize formulas or weak in math. Thus, such learning gives an advantage only to the students who possess intelligence of logic-mathematic compare to other intelligence.

Other examples are the topics of inertia and force which require students to understand the abstract concept of how an object moves or static. This concept is often associated with students' daily life experiences in which moving objects require force throughout their motion. However, the first Newtonian Law states that force acts only when the object moves, stops or changes the direction, rather than continuously in motion. Such abstract representations of force and motion can easily be understood by student with visual spatial intelligence but are difficult to understand by others. Thus, teaching with their own dominant intelligence help students to perform better in their study (Gardner, 1983).

Using online learning also allows students to use interactive elements such as multimedia, animations, icons and storytelling such as on Khan Academy website and Phet Simulation for Physics to make learning physics more fun. For example, learning the concept of momentum in online learning can show videos of the actual or animated collision that can be watched, and the sound of the collision that can be heard. This stimulates visual, musical, interpersonal and mathematical intelligence simultaneously.

As discussed above, there is a wide range of intelligence that is stimulated throughout the learning process. Thus, combining various learning materials that can stimulate multiple intelligence of students to help them better understand force and motion topics; and at same time also help teachers to have good science teaching materials (Choi, Lee, \& Jung, 2008; Redish, 2003). Hence, this study focuses on the multiple intelligence integrated with online learning through the stimulation of the various student's dominant intelligence during learning to help students to understand better the topics of force and motion.

\section{Purpose of the Study}

This study attempted to give answer for the following basic questions:

1. Is there a significant effect of online multiple intelligence-based learning on achievement in physics' motion concept among $10^{\text {th }}$ grade students?

2. Is there a significant effect of online multiple intelligence-based learning on maintaining achievement in physics' motion concept among $10^{\text {th }}$ grade students?

\section{RESEARCH METHODOLOGY}

This study was carried out using a quasi-experiment method of a pre and post-test set of repeated measures on dependent variables (Cambell \& Stanley, 1963; Cohen, Manion, \& Morrison, 2001). The repeated measures are performed to correct the weaknesses of this 
Table 1. Quasi-Experimental Design of a Pre-Post Test Group (Campbell \& Stanley, 1963)

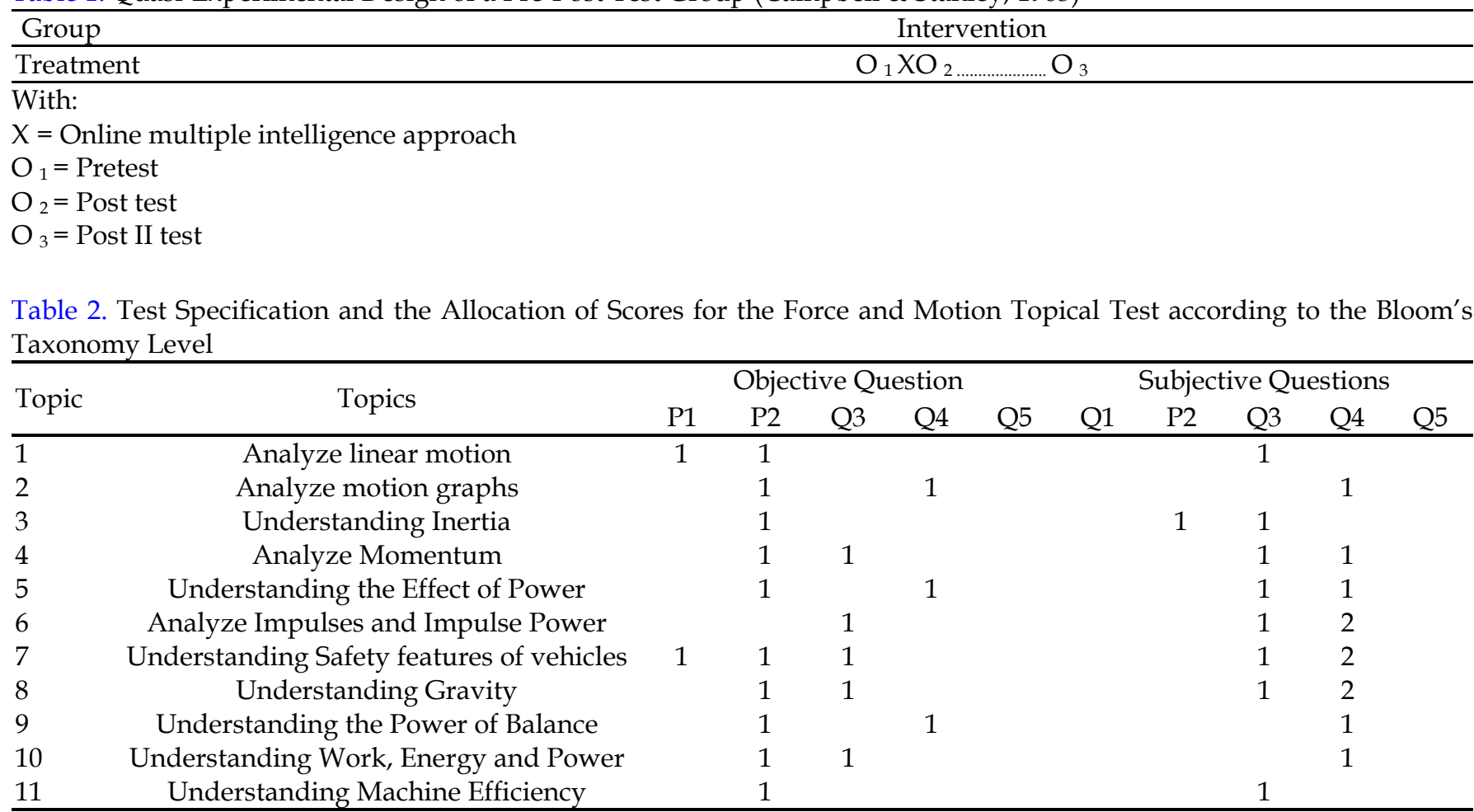

* P1 - Knowledge P 2 - Understanding P3 - Application P4 - Analyze P5 - Synthesis

study's design where it does not have control group and fail to establish control group balance (Best \& Kahn, 2008). The inconsistency of the respondents in the study is that it was extremely difficult to obtain a perfect study sample because each student had different levels of knowledge. This means that all students had to take the same pre and post-test in order to see the impact of the online learning integrated with multiple intelligence approach on their achievement in force and motion topics. Next, the group underwent a post II test to determine the retention of the online learning that integrated multiple intelligence approach. The design of the study used is shown in Table 1.

The study population is $10^{\text {th }}$ grade students from a science junior high school in Malaysia which was randomly selected as the study cases. There were seven classes of the students and a class was randomly selected. However, at the participant level, students were selected as an existing intact group. In this study, the sample in the experimental group was 30 students and this had met the minimum sample size for the experimental study (Krejcie \& Morgan, 1970).

To measure students' achievement, a topical test for force and motion topic was developed according to the physics syllabus format in Malaysian curriculum (MOE, 2012). The test covered 12 sub-topics which was assigned under the topics force and motion. A total of 20 objective questions and three subjective questions were structured according to the test specification that had been developed as shown in Table 2.
The objective section contained 20 questions with three answer choices with each correct answer had a score of one mark. The subjective part consisted of four structural questions with a total of six marks for the first question, eight marks for the second question and six marks for the third question with a total score of 20 marks for this subjective area. The total score for the whole test was 40 marks.

For content validity, this test was evaluated by two teachers with 15 and 18 years of teaching experience respectively in the force and motion topics according to physics syllabus and through test-retest method to improve the weakness of the test if there is any. For reliability test, a pilot study was carried out using quantitative survey approach to obtain information and data to meet the objectives of the study. In this study, a total of another 60 respondents were selected to obtain the reliability test data.

\section{FINDINGS}

To answer the research questions, the descriptive statistics analysis was performed to identify mean values, standard deviations, minimum and maximum values of the pre and post force and motion test for students who followed the online learning integrated with multiple intelligence approach in this study.

To determine whether the data distribution of the study was normal, descriptive statistical methods using skewness cutoff values and kurtosis were based on a range of values between -1 and +1 defined by George and Mallery (2003). The results of the Shapiro-Wilks for Force 
Table 3. Results of the Shapiro-Wilks Force and Motion Statistics Test

\begin{tabular}{lcccc}
\hline & & & Shapiro-Wilks & \\
\cline { 3 - 5 } Force and motion & & Statistics & Degree of Freedom & Significant. \\
\hline & Pre-test & 0.97 & 30 & 0.66 \\
Post test & 0.97 & 30 & 0.56 \\
& Post II test & 0.96 & 30 & 0.33 \\
\hline
\end{tabular}

Table 4. Descriptive Analysis of Min, Standard, Minimum and Maximum Analysis of Overall Pre-test, Post-test and Post II test for Force and Motion

\begin{tabular}{lccc}
\hline & Pre test & Post test & Post II test \\
\hline $\mathrm{N}$ & 30 & 30 & 30 \\
$\mathrm{Min}$ & 42.00 & 57.33 & 60.37 \\
Standard deviation & 7.53 & 7.25 & 9.44 \\
Minimum & 28.00 & 45.00 & 43.00 \\
Maximum & 56.00 & 71.00 & 76.00 \\
\hline
\end{tabular}

Table 5. Multivariate Test Results for Force and Motion

\begin{tabular}{lccc}
\hline & Pre test & Post test & Post II test \\
\hline $\mathrm{N}$ & 30 & 30 & 30 \\
Min & 42.00 & 57.33 & 60.37 \\
Standard deviation & 7.53 & 7.25 & 9.44 \\
Minimum & 28.00 & 45.00 & 43.00 \\
Maximum & 56.00 & 71.00 & 76.00 \\
\hline
\end{tabular}

Table 6. Mauchly Test Results for Force and Motion

\begin{tabular}{cccccc}
\hline Effect over time & Mauchy's Wilky & Khi Power Two & Degree of Freedom & Sig. & Epsilon Greenhouse- Geisser \\
\hline Force and motion & 0.97 & 0.78 & 2 & 0.67 & 0.97 \\
\hline
\end{tabular}

Table 7. Univariate Test Results for Force and Motion

\begin{tabular}{|c|c|c|c|c|c|c|c|c|}
\hline Source & & $\begin{array}{l}\text { Number Two } \\
\text { Power Type III }\end{array}$ & $\begin{array}{l}\text { Degree of } \\
\text { Freedom }\end{array}$ & $\begin{array}{c}\text { Two Min } \\
\text { Power }\end{array}$ & $\mathrm{F}$ & Sig. & $\begin{array}{c}\text { Part Two } \\
\text { Power Two }\end{array}$ & $\begin{array}{c}\text { The power of } \\
\text { observation }\end{array}$ \\
\hline \multirow{2}{*}{$\begin{array}{l}\text { Force and } \\
\text { motion }\end{array}$} & Assumption of & 5816.47 & 2 & 2908.23 & 94.71 & 0.000 & 0.766 & 1.00 \\
\hline & $\begin{array}{l}\text { Greenhouse- } \\
\text { Geisser }\end{array}$ & 5816.47 & 1.95 & 2988.60 & 94.71 & 0.000 & 0.766 & 1.00 \\
\hline
\end{tabular}

and Motion statistical test as shown in Table 3 show a non-significant value $(p>0.05)$ that represents the normally distributed Force and Motion score distribution.

For further descriptive analysis, comparing mean, standard deviation, minimum and maximum for each pre, post-test and post II test as shown in Table 4 .

Overall, the ANOVA tests with repeated measurements were performed to determine the main effect of test time on the dependent variable which was Force and Motion Test. The test time was categorized as within variable used to perform ANOVA tests with repeated measurements. Based on the ANOVA test perspective with repeated measure (Hair et al., 2009), a study variable was considered as an internal variable when the variables were measured repeatedly in the same sample. In the context of this study, test time refers to the Force and Motion Test measured repeatedly on the study sample namely before treatment (pre-test), immediately after treatment (post-test) and after a certain period after treatment (post II test).

The purpose of studying the effect of internal variables was the test time on the dependent variables force and motion to determine whether there were significant changes in Force and Motion Test scores based on repeated measures of Force and Motion test scores. The multivariate test results in Table 5 shows that the main effects of force and motion test time was significant, Wilks' Lamda $=0.150, \mathrm{~F}(1,30)=79.31, \mathrm{p}=$ $0.000, \eta^{2}=0.850$ and the observation power of 1.000 .

Multivariate test results are supported by univariate test results for variables as shown in Table 7. However, to select a univariate test, the assumptions of the faults are first checked using the Mauchly test results as shown in Table 6.

The results of the Mauchly flux test show that the $p$ value obtained was 0.675 which is greater than 0.05 . Based on the obtained values, this indicates that the assumption of covariance matrix variance assumptions 
Table 8. Results of the Bonferroni Test for Force and Motion

\begin{tabular}{lcccc}
\hline Force and motion & & Min & Degree of Freedom of Error & Sig \\
\hline Pre-test & Post test & -15.33 & 2.09 & 0.00 \\
& Post II test & -18.36 & 2.09 & 0.00 \\
\hline Post test & Pre-test & 15.33 & 2.09 & 0.00 \\
& Post II test & -3.033 & 2.09 & 0.00 \\
\hline Post II test & Pre-test & 18.36 & 2.09 & 0.00 \\
& Post test & 3.033 & 2.09 & 0.00 \\
\hline
\end{tabular}

Table 9. Test Results Estimated Marginal Means Force and Motion

\begin{tabular}{lccc} 
& & \multicolumn{2}{c}{ 95\% Confidence Interval } \\
\cline { 3 - 4 } Force and motion & Min & Lower Limit & Upper Limit \\
\hline Pre-test & 42.00 & 39.04 & 44.95 \\
Post test & 57.33 & 54.38 & 60.28 \\
Post II test & 60.36 & 57.41 & 63.31 \\
\hline
\end{tabular}

Table 10. Friedman's test of Pre, Post and Post Scores of Force and Motion for All Intelligence

\begin{tabular}{lcccc}
\hline Multiple intelligence & $\mathrm{N}$ & Khi Power Two & Degree of Freedom & Sig. \\
\hline Verbal Linguistics & 3 & 6.00 & 2 & 0.05 \\
Mathematical Logic & 7 & 8.86 & 2 & 0.01 \\
Kinesthetic & 3 & 4.67 & 2 & 0.09 \\
Music & 3 & 4.67 & 2 & 0.09 \\
Space Visuals & 3 & 6.00 & 2 & 0.03 \\
Interpersonal & 5 & 7.60 & 2 & 0.02 \\
Intrapersonal & 3 & 6.00 & 2 & 0.03 \\
Naturalist & 3 & 4.67 & 2 & 0.09 \\
\hline
\end{tabular}

is obeyed (Howell, 2009). For univariate tests, there was a significant main effect of test time on force and motion scores, $\mathrm{F}=94.71, \mathrm{p}=0.00$ and $\eta^{2}=0.76$ and observation power of 1.00 .

Multivariate and univariate test results are significant, and this means that there was one test pair that had a mean difference in force and motion scores, which is:

i- mean score of pre-Force and Motion test with a mean score of post test

ii - mean score of pre-Force and Motion test with post II scores

iii. mean score of post Force and Motion test with post II scores

Based on the results of the Bonferroni test in Table 8 , there was a significant difference $(\mathrm{p}<0.05)$ in the mean pair of pre and post scores.

To see this pattern of change, the estimated marginal mean force and motion obtained values are used to see the mean change in mean score for the absorption of each test performed. The results in Table 9 shows that the mean value of pre-test and motion scores was 42.00 and the mean value of force and motion post scores was 57.33 with mean increase from pre-treatment to posttreatment.

Furthermore, the findings in Table 9 show that the mean value of pre-test and motion scores was 42.00 and the mean post-test and motion post II test were 60.36 with a mean increase from pre-treatment to posttreatment. This finding is supported by the findings in
Table 8 which show that there was a significant difference between the mean test pre and post test score and post II test scores. Thus, it can be concluded that the online intelligence approach had a significant impact on the positive force and motion among the study samples from pre-test to advanced post-test.

The findings in Table 9 show that the mean score of post Force and Motion Test was 57.33 and the mean score of post II force and motion was 60.36 with mean increase from pre-treatment to post II treatment. This finding is supported by the findings in Table 8 which show that there were significant differences between the mean post force and motion test scores to post II test scores. Therefore, it can be concluded that the online intelligence approach had a significant impact on the positive force and motion among the study sample from post-test to post II test.

Next, the analysis was performed to identify the relationship between student intelligence tendencies and force and motion test scores using Friedman's nonparametric analysis (Piew, 2013) and the results are shown in Table 10.

Wilcoxon test was carried out for each pair of pre-test, post-test and post II test for verbal intelligence as shown in Table 11.

The results of the Wilcoxon Test found that all pairs of force and motion score tests for this verbal intelligence were not significant at the $\mathrm{p}<0.05$ level, and overall results based on the Friedman test showed there was no 
Table 11. The Wilcoxon Test for Pre, Post and Post II Scores on Force and Motion for Verbal Intelligence

\begin{tabular}{lccc}
\hline Intelligence & Force and motion test & Z & Sig \\
\hline Verbal & Pre-test & 1.60 & 0.10 \\
& Post test & 1.60 & 0.10 \\
& Post II test & 1.60 & 0.10 \\
\hline
\end{tabular}

$\mathrm{p}<0.05$

Table 12. Wilcoxon's Test of Pre, Post and Post II Scores of Force and Motion for Logic Intelligence

\begin{tabular}{lccc}
\hline Intelligence & Force and motion test & Z & Sig \\
\hline Logic & Pre-test & 2.20 & 0.02 \\
& Post test & 2.36 & 0.01 \\
& Post II test & 0.67 & 0.49 \\
\hline
\end{tabular}

$\mathrm{p}<0.05$

Table 13. Wilcoxon's Test of Pre, Post and Post II Scores on Force and Motion for Kinesthetic Intelligence

\begin{tabular}{lccc}
\hline Intelligence & Force and motion test & Z & Sig \\
\hline Kinesthetic & Pre-test & 1.60 & 0.10 \\
& Post test & 1.60 & 0.10 \\
& Post II test & 1.06 & 0.28 \\
\hline
\end{tabular}

$\mathrm{p}<0.05$

Table 14. Wilcoxon's test of pre-, post-and-post scores of force and motion for Music intelligence

\begin{tabular}{lccc}
\hline Intelligence & Force and motion test & Z & Sig \\
\hline Music & Pre-test & 1.60 & 0.10 \\
& Post test & 1.60 & 0.10 \\
& Post II test & 0.53 & 0.59 \\
\hline
\end{tabular}

$\mathrm{p}<0.05$

Table 15. Wilcoxon's test of pre-, post-and-post scores of force and motion for Visual intelligence

\begin{tabular}{lccc}
\hline Intelligence & Force and motion test & Z & Sig \\
\hline Visual & Pre-test & 1.60 & 0.03 \\
& Post test & 1.60 & 0.03 \\
& Post II test & 1.60 & 0.03 \\
\hline
\end{tabular}

$\mathrm{p}<0.05$

significant difference between the tests $\left[x^{2}(2, N=3)=\right.$ 6.00, $\mathrm{p}<0.05$ ] as shown in Table 10.

Next is the Wilcoxon test results for logic intelligence as shown in Table 12.

The results of the Wilcoxon Test found that only two pairs of force and motion scores test for this Mathematical Logic intelligence were significant at the $p$ $<0.05$ level although overall results based on the Friedman test shows there were significant differences between the tests $\left[\mathrm{x}^{2}(2, \mathrm{~N}=7)=8.86, \mathrm{p}<0.05\right]$ as shown in Table 10.

Next is the Wilcoxon test results for Kinesthetic intelligence (See Table 13).

The results of the Wilcoxon Test found that all pairs of force and motion scores for the Kinesthetic intelligence were not significant at the $p<0.05$ level, and overall results based on the Friedman test shows there was no significant difference between the tests $\left[x^{2}(2, N\right.$ $=3)=4.67, \mathrm{p}<0.05]$ as shown in Table 10 .

Next is the Wilcoxon test for Music intelligence (See Table 14).
The results of the Wilcoxon Test found that all pairs of force and motion scores for Music intelligence were not significant at the $\mathrm{p}<0.05$ level, and overall results based on the Friedman test showed no significant difference between the tests $\left[x^{2}(2, N=3)=4.67, p<0.05\right]$ as shown in Table 10.

Next is the Wilcoxon test results for the Visual intelligence shown in Table 15.

The results of the Wilcoxon Test found that all pairs of force and motion scores for this Visual intelligence were significant at the $p<0.05$ level, and overall results based on the Friedman test shows there were significant differences between the tests $\left[x^{2}(2, N=3)=6.00, p<0.05\right]$ as shown in Table 10.

Next is the Wilcoxon test results for Interpersonal intelligence shown in Table 16.

The results of the Wilcoxon Test found that only two pairs of force and motion scores for the Interpersonal intelligence were significant at the $p<0.05$ level although overall results based on the Friedman test shows there 
Table 16. Wilcoxon test for pre-, post and post scores on force and motion for Interpersonal intelligence

\begin{tabular}{lccc}
\hline Intelligence & Force and motion test & Z & Sig \\
\hline Interpersonal & Pre-test & 2.03 & 0.04 \\
& Post test & 2.03 & 0.04 \\
& Post II test & 0.94 & 0.34 \\
\hline
\end{tabular}

$\mathrm{p}<0.05$

Table 17. The Wilcoxon test for pre, post and post II scores on force and motion for Intrapersonal intelligence

\begin{tabular}{lccc}
\hline Intelligence & Force and motion test & Z & Sig \\
\hline Intrapersonal & Pre-test & 1.60 & 0.03 \\
& Post test & 1.60 & 0.03 \\
& Post II test & 1.60 & 0.03 \\
\hline
\end{tabular}

$\mathrm{p}<0.05$

Table 18. Wilcoxon's test of pre, post and post II scores of force and motionfor Naturalist intelligence

\begin{tabular}{lccc}
\hline Intelligence & Force and motion test & Z & Sig \\
\hline Naturalist & Pre-test & 1.60 & 0.10 \\
& Post test & 1.60 & 0.10 \\
& Post II test & 1.06 & 0.28 \\
\hline
\end{tabular}

$\mathrm{p}<0.05$

Table 19. Mean Values and Changes in Mean Values for Force and Motion Score

\begin{tabular}{cccccc}
\hline & \multicolumn{3}{c}{ Mean Value } & \multicolumn{2}{c}{ Changes in Mean Values } \\
\cline { 2 - 6 } Multiple Intelligence & Pre test & Post test & Post test II & $\begin{array}{c}\text { Post- } \\
\text { pre-test }\end{array}$ & $\begin{array}{c}\text { Post test II - } \\
\text { post test }\end{array}$ \\
\hline Verbal Linguistics & 45.33 & 53.33 & 60.67 & 8.00 & 7.34 \\
Mathematical Logic & 36.43 & 51.86 & 53.71 & 15.43 & 1.85 \\
Kinesthetic & 44.33 & 58.67 & 64.33 & 14.34 & 5.66 \\
Music & 43.00 & 53.33 & 49.67 & 10.33 & -3.66 \\
Space Visuals & 45.33 & 59.67 & 65.67 & 14.34 & 6.00 \\
Interpersonal & 43.00 & 59.80 & 62.80 & 16.80 & 3.00 \\
Intrapersonal & 46.67 & 61.33 & 63.00 & 14.66 & 7.67 \\
Naturalist & 48.67 & 55.67 & 60.00 & 7.00 & 4.33 \\
\hline
\end{tabular}

were significant differences between the tests $\left[\mathrm{x}^{2}(2, \mathrm{~N}=\right.$ $5)=7.60, p<0.05]$ as shown in Table 10 .

Next is the Wilcoxon test results for Intrapersonal intelligence as shown in Table 17.

The results of the Wilcoxon Test found that all pairs of force and motion scores for this Intrapersonal intelligence were significant at the $\mathrm{p}<0.05$ level, and overall results based on the Friedman test showed significant differences between the tests $\left[x^{2}(2, N=3)=\right.$ 6.00, $\mathrm{p}<0.05$ ] as shown in Table 10.

Next is the Wilcoxon test result for Naturalis intelligence (See Table 18).

The results of the Wilcoxon Test found that all pairs of force and motion scores for the Naturalist's intelligence were not significant at the $\mathrm{p}<0.05$ level, as the overall results based on the Friedman test shows there was no significant difference between the tests [ $\mathrm{x}^{2}$ $(2, \mathrm{~N}=3)=6.00, \mathrm{p}<0.05$ ] as shown in Table 10 .

As a summary, Table 19 shows the mean values for each pre, post and post II test for each intelligence indicating that all of the intelligences showed an increase in the achievement of scores either from pre to post-test or from post to post II test.

In summary, the overall results of force and motion score analysis of each intelligence had an increase that reflected the teaching methodology built with integrating the multiple intelligence in this study capable of stimulating all such intelligence. However, Wilcoxon and Friedman's analysis shows that only the Logic, Interpersonal and Intrapersonal Logic intelligence had significant changes in force and motions scores. This is in line with Gardner's (1999) assertion that some intelligence can be simultaneously stimulated by assisting technology in student learning and teaching.

\section{DISCUSSION}

The findings in this study show that the online learning integrating multiple intelligences had a significant impact on the achievement of the force and motion achievement test among $10^{\text {th }}$ grade students. Significant hypothesis test results for mean improvement in pre and post test scores indicates that the impact on the achievement of the force and motion topics had increased after the students followed the 
online learning that integrated multiple intelligences built in this study. The results of the non-significant hypothesis post and post II test show that there was a retention of positive effects on the achievement of the force and motion topics after six weeks of intervention. These results indicate that the mean differences in the test effects before and after the intervention were because of the online learning integrating multiple intelligences intervention itself.

In analyzing the relationship between each of the intelligence to force and motion scores, it was found that Mathematical, Interpersonal and Intrapersonal intelligence also had showed significant changes but only for differences between pre and post-tests as well as post and post II test.

In this study, the implementation of the learning method was based on the online learning integrated with multiple intelligences which was developed based on Multiple Intelligence and Constructivism Theories to enhance the achievement of force and motion topics among students. The constructivism theory states that learning is an active learning process in which students use various senses as inputs and build knowledge through the interpretation and processing of information from such inputs (Barr, 2003; Legal, 2014; Trif, 2015).

The online learning integrating multiple intelligences in this study by using online learning had provided methods for students to actively seek, build and process information either through their own learning or by actively engaging with students and teachers. The analysis of the online communication application like WhatsApp show that all students were engaged in discussions and were diligent in providing feedback during their learning. This had reduced students' passivity, lack of concentration, or even sleeping in the conventional classroom. The results of this study were also in line with the study by Ainley (2012), Harackeiew et al. (2012), Wang and Park (2012), and Greenhow, Robelia and Hughes (2009b) which state that students who were active in online learning could enhance their understanding and achievement of a subject or concept that they were learning.

The constructivism theory states that students build new knowledge through their past experience and existing knowledge (Alexander, 2006) and use their own intelligence to build new experiences and knowledge through practical and hands-on activities (Bachtold, 2013; Harlow et al., 2013; Moford, 2014). The online learning in this study had integrated multiple intelligences method which incorporated Physlet simulation applications for graph-based online apps for motion linear as well as TinkerCad's design application to design their own aerodynamics cars. Such activities are interactive and make learning more student-centred rather than conventional learning that only uses reference books and doing exercises (Duane \& Satre, 2014; Harlow et al., 2013).

The findings in the interviews show that students were eager to use online learning which had integrated multiple intelligences to learn physics subjects at school. One of the students reported that he was looking forward to physics class and he was eager to complete the assignment. This shows that students were active and responsible in their own learning. In addition, knowledge from past experiences can be retained in order to build new knowledge thereafter (Cohen, 2004; Elkin, 2005). This is in line with the findings of the study showing that there was an increase in mean post test scores and mean post II test mean scores although there were not significant. This finding shows that the use of the online learning integrating multiple intelligences in this study was also effective in maintaining the knowledge that was built during the learning process.

The use of online learning integrated with multiple intelligences in this study also had required the students to actively seek out information on the topics which was being studied to build new knowledge. The use of Google search engines and Wiki facilitates students with linguistic verbal intelligence to work on the information they need and also stimulates naturalist intelligence to gather, classify and categorize that information in the learning they love (Gen, 2000). It also stimulates the mathematical logic aspect for the students to learn better when all learning materials can be linked and understood logically. The online learning integrated with multiple intelligences in this study also features virtual digital storage that stimulates the visual intelligence to constantly use it in every project they produce (Armstrong, 2000).

Collaborative and cooperative learning are also encouraged in the learning based in constructivism (Palloff \& Pratt, 1999) where knowledge building is made easier when students interact with other students and teachers (Murphy \& Cifuentes, 2001). The online learning integrated with multiple intelligences in this study had incorporated these collective and cooperative aspects through project-based learning to work as a team. This is in line with studies that found that students learn better in groups than individuals (Brown \& Adler, 2008) and in line with Boss and Krauss's (2007) study that used similar methods to build knowledge through online learning experiences. Project-based learning enables students to engage in exploration, collaboration, free discussion, sharing ideas and exchanging information with each other (Gray \& Xiaoli, 2001) to produce the final product for a given task. In using this project-based learning method, students acknowledge that discussions in the group make learning fun, reduce boredom, enhance ideas, and help students complete assigned tasks. 
Through analyzing the usage of the online communication application such as WhatsApp, the students were able to express themselves, exchange information and comment on the final product made by friends from other groups. Observations and feedback from teachers also indicated that students focused on their work while using the online learning integrated with multiple intelligences in this study from early group discussions until final assessment and project presentation. According to Harlen (1999) such learning enables students to be open-minded and critical while enhancing their understanding and achievement in the subject being studied.

The findings of the advanced analysis of force and motion topics mean scores on each intelligence had showed that all multiple intelligence elements increased in force and motion scores; however, only interpersonal and intrapersonal intelligence shows there was significant improvement. Interpersonal intelligence is the ability to interact with and understand others (Brougher, 1997; Gardner, 1983) and the online group discussions conducted make it more attractive, avoiding students from the embarrassment of asking questions and encouraging acceptance (Chin \& Osborne, 2008). Quick feedback from teachers and classmates makes the discussion livelier and helps students with intrapersonal intelligence to understand learning materials more easily (Rhodes \& Bellamy, 1999). The findings of the online communication using WhatsApp application show that all students were interested and passionate about it. While there were some students who were dominant and frequently gave their views, but others also supported or discussed solutions that was used to complete the project assignments in this project-based learning. This is in line with Lamb's (2004) study which found that activities involving project performance also stimulated this intelligence.

\section{CONCLUSIONS AND IMPLICATIONS OF THE STUDY FINDINGS}

In conclusion, the findings of the online learning integrated with multiple intelligences in this study support the constructivism learning theory that emphasizes the principle of active learning even when conducted online (Gulbhar \& Tinmaz, 2006; SidmanTaveau, 2005; Welsh, 20006). Through online learning that integrated multiple intelligences in this study, the students build knowledge through social interaction (Anderson, 2003) as well as share information collectively to build new knowledge (Atherto, 2005; Ngambi \& Lombe, 2012). Communication and collaboration in online assignments and quick feedback in discussions helps students with intrapersonal intelligence to understand learning materials more easily (Rhodes \& Bellamy, 1999). Active participation in group work also indirectly always motivates students to constantly seek information. This continuous effort was able to retain students' knowledge on a long-term or sustainable basis (Colquit \& Neo, 2000).

Physics learning often has problems with the lack of interactive learning materials that can be used to facilitate and diversify teaching and learning methods (Greenhow \& Robelia, 2009a). The online learning method is a new alternative to the one-way chalk and talk methods in today's conventional classroom (Ramlah \& Mahani, 2002). The online learning integrated with multiple intelligence method built in this study utilized a variety of online applications and activities enabling students to generate knowledge and improve the achievement of physics subjects in force and motion topics. The implications of this study suggest that the use of online learning integrated with multiple intelligences had the potential to positively impact learning and enhance student achievement in the force and motion topics. The activities in the online learning integrating multiple intelligences were more student-centred and met their needs in the use of technology and this enables them to learn more and actively involved in their learning (Lou et al., 2010). Furthermore, the online learning integrated with multiple intelligence in physics classes had the potential to provide an interactive learning environment that enabled students to learn selfsufficiency, engage in a variety of activities and explore greater and better learning materials. The teachers are no longer the content experts but rather as facilitators who provide guidance to students (Senocak, 2007).

In conclusion, the findings from this study also found that the online learning integrating multiple intelligences method was able to stimulate intelligence and improve problem solving skills through assigned project tasks to make it more relevant to the real-life context of students, thus, was able to attract students, enhance their skills and personal knowledge and ultimately improve student achievement.

\section{ACKNOWLEDGEMENTS}

This research has been funded under TIER1 Research Fund Vot. H842 from the Research Management Center (RMC) University Tun Hussein Onn Malaysia (UTHM).

\section{REFERENCES}

Abdul Rahim, K., \& Selamat, S. R. (2014). Penerapan Teori Kecerdasan Pelbagai dalam Pengajaran JenisJenis Ayat [Application of Multiple Intelligences Theory in the Teaching of Sentence Types]. Seminar Bahasa Melayu 2014.

Ainley, M. (2012). Students' Interest and Engagement in Classroom Activities. In Handbook of research on student engagement. New York: Springer-Verlag New York Inc. https://doi.org/10.1007/978-14614-2018-7_13 
Alexander, B. (2006). Web 2.0: A new wave of innovation for teaching and learning? EDUCAUSE Review, 41(2), 32-44.

Anderson, P. (2007). What is Web 2.0? Ideas, technologies, and implications for education. JISC Technology and Standards Watch. Retrieved from http://www. ictliteracy.info/rf.pdf/Web2.0_research.pdf

Armstrong, T. (2000). In their own way: Discovering and encouraging your child's multiple intelligences (rev. and updated ed.). New York, NY: Penguin Putnam.

Bachtold M. (2013). What Do Students "Construct" According to Constructivism in Science Education? Research in Science Education, 43(6), 2477-2496. https: / / doi.org/10.1007/s11165-013-9369-7

Best, J. W., \& Kahn, J. V. (2008). Research in Education (10 th Ed.). India: Prentice Hall.

Boss, S., \& Krauss, J. (2007). Reinventing project-based learning: Your field guide to real-world projects in the digital age. Washington, DC: International Society for Technology in Education.

Brown, J. S., \& Adler, R. P. (2008). Minds on fire: Open education, the long tail, and learning 2.0. Educause Review, 43(1), 16-32.

Cambell, D. T., \& Stanley, J. C. (1963). Experimental and quasi-experimental design for research. Chicago: Rand Menally.

Chien, C.-F., Chen, G. Y.-H., \& Liao, C.-J. (2019). Designing a Connectivist Flipped Classroom Platform Using Unified Modelling Language. Journal of Online Pedagogy and Course Design, 9(1), 118. https:/ / doi.org/10.4018/IJOPCD.2019010101

Chin, C., \& Kayalvizhi, G. (2005). What Do Pupils Think of Open Science Investigations? A Study of Singaporean Primary 6 Pupils. Educational Research. 47(1), 107-126. https:/ / doi.org/10.1080/001318804 2000337596

Chin, C., \& Osborne, J. (2008). Students' questions: a potential resource for teaching and learning science. Studies in Science Education, 44(1), 1-39. https://doi.org/10.1080/03057260701828101

Choi, I., Lee, S. J., \& Jung, J. W. (2008) Designing Multimedia Case-Based Instruction Accommodating students' Diverse Learning Style. Journal of Educational Multimedia and Hypermedia, 17(1), 5-25.

Chung, K. C. (2008). Antecedent of Brand Trust in Online Tertiary Education: A Malaysian and Singapore Perspective. International Journal of Business and Management, 3(4), 3-10. https://doi.org/10.5539/ ijbm.v3n4p3

Cohen, L., Manion. L., \& Morrison, K. (2001). Research Methods in Education (5 ${ }^{\text {th }}$ Ed.). New York: Routledge Falmer.
Colquitt, J. A., Lepine, J. A., \& Noe, R. A. (2000). Toward an integrative theory of training motivation; A meta-analytic path analysis of 20 years of research. Journal of Applied Psychology, 85(5), 678-707. https:/ / doi.org/10.1037/0021-9010.85.5.678

Elkins, J. (2007). Learning disabilities: Bringing fields and nations together. Journal of Learning Disabilities, 40, 392-399. https://doi.org/10.1177/0022219407 0400050201

Erinosho, S. Y. (2013). How Do Students Perceive the Difficulty of Physics in Secondary School? An Exploratory Study in Nigeria. International Journal for Cross-Disciplinary Subjects in Education (IJCDSE), Special Issue Volume 3 Issue 3. https://doi.org/ 10.20533/IJCDSE.2042.6364.2013.0212

Gardner, H. (1999). Intelligence reframed. New York, NY: Basic Books.

Gen, R. (2000). Technology and multiple intelligences. ED at a Distance, 15(5), 4-9.

George, G., \& Mallery, P. (2003). SPSS for windows step by step: A simple guide and reference, 11.0 update. Boston, MA: Allyn \& Bacon.

Gray, K. C., \& Xiaoli, C. (2001). Computer and internet usage in education: Theories, practice, and research basics. Journal Educational Technology System, 29(1), 41-48. https:/ / doi.org/10.2190/87H6-RA7J-V9K90U21

Greenhow, C., \& Robelia, B. (2009a). Old communication, new literacies: Social network sites as social learning resources. Journal of Computermediated Communication, 14(4), 1130-1161. https:/ / doi.org/10.1111/j.1083-6101.2009.01484.x

Greenhow, C., Robelia, B., \& Hughes, J. E. (2009b). Learning, Teaching, and Scholarship in a Digital Age: Web 2.0 and Classroom Research--What Path Should We Take "Now"? Educational Researcher, 38(4), 246-259. https://doi.org/10.3102/0013189X 09336671

Hair, J. F. H., Anderson, R. E., Tatham, R. L., \& Black, W. C. (2009). Multivariate data analysis (7th Ed.). Prentice Hall: New Jersey.

Halpern, D. F. (2002). Cognitive Science and the Work of Reform. In J. L. Narum \& K. Conover (Eds.), Building Robust Learning Environment in Undergraduate Science, Technology, Engineering and Mathematics. San Francisco: Jossey-Bass.

Harlen, W. (1999). Purposes and Procedures Assessing Science Process Skill. Assessment in Education, 6(1), 129-144. https:/ / doi.org/10.1080/09695949993044

Howell, A. J., \& Buro, K. (2009). Implicit beliefs, achievement goals, and procrastination: a mediational analysis. Learning and Individual Differences, 19, 151-154. https://doi.org/10.1016/ j.lindif.2008.08.006 
Krejcie, R. V., \& Morgan, D. W. (1970). Determining sample size for research. Educational and Psychological Measurements, 30, 607-610. https: / doi.org/10.1177/001316447003000308

Mantyla, T., \& Koponen, I. T. (2007). Understanding the Role of Measurements in Creating Physical Quantities: A Case Study of Learning to Quantify Temperature in Physics Teacher Education. ScienceE Education, 16(3), 291-311. https:/ / doi.org/10.1007/s11191-006-9021-2

Ministry Education of Malaysia (MOE) (2012). Spesifikasi Kurikulum Fizik Tingkatan Empat [Fourth Level Physical Curriculum Specifications]. Bahagian Pembangunan Kurikulum KPM. Kuala Lumpur.

Murphy, K. L., \& Cifuentes, L. (2001). Using web tools, collaborating, and learning online. Distance Education, 22(2), 285-305. https:/ / doi.org/10.1080/ 0158791010220207

Neset, D. (2005). The effect of web-based homework on university students' physics achievements. Turkish Online Journal of Educational Technology, 9(4), 156161.

Ng'ambi, D., \& Lombe, A. (2012). Using Podcasting to Facilitate Student Learning: A Constructivist Perspective. Educational Technology \& Society, 15(4), 181-192.

Nik Daud, N. S., Abd Karim, M. M., Wan Hassan, S. W., \& Rahman, N. (2015). Misconception and Difficulties in Introductory Physics Among High School and University Students: An Overview in Mechanics (34 - 47). EDUCATUM Journal of Science, Mathematics and Technology (EJSMT), 2(1), 34-47.

Palloff, R. M., \& Pratt, K. (2001). Lesson from the cyberspace classroom: The realities of online teaching. San Francisco: Jossey-Bass Inc.

Piew, C. Y. (2013). Asas Statistik Penyelidikan [Basic Research Statistics: Second Edition] (2nd Ed.). McGraw Hill.

Pulit anak Lai (1998). Mengkaji Strategi Pengajaran Fizik di Sekolah: Satu Kajian Kes di beberapa Sekolah Daerah Kajang, Selangor [Studying Physics Teaching Strategies in Schools: A Case Study in Several Kajang District Schools, Selangor] (Unpublished Thesis). Bangi: Universiti Kebangsaan Malaysia.
Ramlah, J., \& Mahani, R. (2002). Psikologi Pendidikan: Pendekatan Kontemporari [Educational Psychology: A Contemporary Approach]. Kuala Lumpur: McGrawHill (Malaysia) Sdn. Bhd.

Redish, E. F. (2003). Teaching Physics with the Physics Suite. John Wiley \& Sons, Inc.

Rhodes, L. K., \& Bellamy, T. (1999). Choices and consequences in the reform of teacher education. Journal or Teacher Education, 50, 17-26. https: / / doi.org/10.1177/002248719905000103

Sandra, R., Abu Bakar, N., \& Norlidah. A, (2013). Penggunaan ICT merentas kurikulum standard prasekolah kebangsaan (kspk): tinjauan di prasekolah kementerian pelajaran Malaysia [Use of ICT across the national preschool standard curriculum (kspk): survey in preschools ministry of education Malaysia]. Jurnal Kurikulum dan Pengajaran Asia Pasifik, 1(4), 65.

Shy-Jong, J. (2007). A Study of Students' Construction of Science Knowledge: Talk and Writing in a Collaborative Group. Educational Research, 49(1), 6581. https:/ / doi.org/10.1080/00131880701200781

Sidman-Taveau, R. \& Milner-Bolotin, M. (2001). Constructivist inspiration: A project-based model for L2 learning in virtual worlds. Texas Papers in Foreign Language, 6(1), 63-82.

Trif, L. (2015). Training models of social constructivism: Teaching based on developing a scaffold. Procedia Social and Behavioral Sciences: The 6th International Conference Edu World, 2014. https://doi.org/ 10.1016/j.sbspro.2015.02.184

Wang, C. H., Shannon, D. M., \& Ross, M. E. (2013). Student' characteristics, self regulated learning, technology self-efficacy, and course outcomes in online learning. Distance Education, 34(3), 302-323. https://doi.org/10.1080/01587919.2013.835779

Wang, Y. D. (2014). Building student trust in online learning environment. Distance Education, 35(3), 345- 359. https://doi.org/10.1080/01587919.2015. 955267

Welsh, E. T., Wanberg, C. R., Brown, E. G., \& Simmering, M. J. (2003). E-learning: emerging uses, empirical results and future directions. International Journal of Training and Development, 7(4), 245-258. https://doi.org/10.1046/j.1360-3736.2003.00184.x

\section{http://www.ejmste.com}

